\title{
Interleukin-6 (IL-6) Gene Expression and Secretion by Cytokine- stimulated Human Retinal Pigment Epithelial Cells
}

\author{
VICTOR M. ELNER ${ }^{a, b}$, WENDY SCALES ${ }^{c}$, SUSAN G. ELNER* JEAN DANFORTH ${ }^{a}$, \\ STEVEN L. KUNKEL ${ }^{b}$, AND ROBERT M. STRIETER ${ }^{d}$ \\ Departments of a Ophthalmology (Kellogg Eye Center), ${ }^{b}$ Pathology, ${ }^{c}$ Surgery, and ${ }^{d}$ Internal Medicine, \\ University of Michigan, Ann Arbor, MI 48109, U.S.A.
}

\author{
(Received Houston 4 December 1990 and accepted in revised form 2 April 1991)
}

\begin{abstract}
Retinal and choroidal inflammatory lesions are important causes of visual loss, but the mechanisms regulating intraocular inflammation remain poorly understood. By virtue of its position at the blood-retina barrier, the retinal pigment epithelium (RPE) cells may be critical to the initiation and propagation of ocular inflammation. Previously we showed that cytokine-stimulated RPE cells produce interleukin-8, a well-defined chemotactic factor for neutrophils and lymphocytes. In this study, we found that human RPE cells stimulated by human recombinant interleukin-1- $\beta$ ( $r$ IL-1 $\beta$ ) or tumor necrosis factor- $\alpha$ (rTNF- $\alpha$ ) produce interleukin-6 (IL-6). Using a plasmacytoma proliferation assay, significant levels of IL- 6 were found in media of RPE cells stimulated with either rIL-1 $\beta$ or rTNF- $\alpha$ for $4 \mathrm{hr}$. Progressive accumulation of IL- 6 in media overlying stimulated RPE cells occurred over the subsequent $20 \mathrm{hr}$. IL- $1 \beta$ was a significantly more potent stimulator of RPE IL- 6 production than TNF- $\alpha$. RPE IL- 6 production in response to each of these cytokines was also dose-dependent over a range of $20 \mathrm{pg}$ to $20 \mathrm{ng}$ $\mathrm{ml}^{-1}$. Specific anti IL-6 antibody, but not control immunoglobulin. neutralized RPE-derived IL-6 activity in the plasmacytoma proliferation assays. RPE IL- 6 mRNA levels were detectable $1 \mathrm{hr}$ after cytokine stimulation, plateaued within $8 \mathrm{hr}$ in 24-hr assays, and demonstrated dose-dependent kinetics in $6 \mathrm{hr}$ assays. Lipopolysaccharide failed to induce RPE IL- 6 mRNA expression or RPE IL-6 production. Our findings indicate that RPE cells express IL- 6 mRNA and secrete biologically active IL- 6 when stimulated by inflammatory cytokines. RPE IL- 6 secretion may be important in ocular lesions involving differentiation and activation of lymphocytes.

Key words : retinal pigment epithelium : interleukin-6: cytokines : interleukin- 1 ; tumor necrosis factor ; lipopolysaccharide.
\end{abstract}

\section{Introduction}

Leukocytic infiltration of the choroid, retina, and vitreous is an important pathogenetic feature of a wide spectrum of inflammatory, vascular, degenerative, and dystrophic diseases of the retina and choroid (Green, 1985), but the mechanisms important in eliciting and propagating intraocular inflammation remain largely unknown. The neuroectodermallyderived retinal pigment epithelium (RPE) consists of a monolayer of cells that is strategically located between choroidal blood circulation and the neurosensory retina. As part of the blood-retina barrier (Marmor and Zinn, 1979), the RPE is positioned to interact with neural cells in the retina and leukocytes emerging from choroidal vessels, thereby enabling it to perform critical roles in the initiation and propagation of ocular inflammation. The identification of RPE FC and C3bi receptors (Elner et al., 1981) and the expression of RPE HLA-DR antigens following interferon- $\gamma$ (IFN$\gamma$ ) stimulation and in retinal diseases (Detrick et al., 1985, 1986; Chan et al., 1986) imply roles for RPE cells in ocular inflammation. Active participation of

* For correspondence at: Kellogg Eye Center, University of Michigan, 1000 Wall Street, Ann Arbor, MI 48105, U.S.A. the RPE in the regulation of retinal and choroidal leukocyte infiltration is suggested by recent studies in which we have demonstrated that human RPE cells stimulated with human recombinant interleukin-1- $\beta$ (rIL- $\beta$ ) or recombinant tumor necrosis factor- $\alpha$ (rTNF$\alpha)$ produce interleukin-8 (IL-8) which is chemotactic for neutrophils and lymphocytes (Elner et al., 1990).

In this study, we report that human RPE cells synthesize and secrete $\Pi-6$ when exposed to physiologic concentrations of rIL- $\beta$ or rTNF- $\alpha$, inflammatory cytokines which are known to be secreted by leukocytes and tissue-based vascular endothelial cells, fibroblasts, astrocytes and Mueller cells (Roberge, Caspi and Nussenblatt, 1988; Akira et al., 1990). IL-6 production by resident, neural-derived RPE cells in response to inflammatory cytokines may be important in the initiation and propagation of retinal and choroidal inflammations, involving recruitment, activation, and proliferation of T- and B-lymphocytes.

\section{Materials and Methods}

Human RPE Cell Cultures

Human RPE cells were isolated from donor eyes within $24 \mathrm{hr}$ of death using a modification of the 
method of Edwards (1982) as previously performed (Elner et al., 1990). In brief, the sensory retina was gently separated from the RPE monolayers which was then trypsinized $(0 \cdot 25 \%)$ for $30-40$ min from Bruch's membrane into serum-free DMEM containing $0.02 \mathrm{mg}$ $\mathrm{ml}^{-1}$ DNase I (Sigma Chemical Co., St Louis, MO). Following centrifugation and resuspension in Dulbecco's Modified Essential Medium (DMEM) containing $15 \%$ fetal bovine serum, penicillin $\mathrm{G}\left(100 \mathrm{U} \mathrm{ml}^{-1}\right)$, streptomycin sulfate $\left(100 \mu \mathrm{g} \mathrm{ml}^{-1}\right)$, and amphotericin $\mathrm{B}\left(2.5 \mu \mathrm{g} \mathrm{ml}^{-1}\right)$ (Gibco Inc., Grand Island, NY), the RPE cells were seeded into $25-\mathrm{cm}^{2}$ Falcon Primaria flasks (Becton-Dickinson Inc., Lincoln Park, NJ) to inhibit fibroblast growth. Cells were passaged by trypsinization, and plating at $5 \times 10^{5} \mathrm{RPE}$ cells per flask resulting in near confluent (>90\%: about $1.5 \times 10^{6}$ RPE cells per flask) cultures in 5-7 days. In confluent cultures, each of the three RPE cell lines used displayed distinctive morphologic features typical for RPE cells, including growth in monolayers composed of polygonal cells.

To cxclude the possibility of contaminating cell types, RPE cultures were examined using various markers. The RPE monolayers exhibited uniform immunohistochemical staining for fibronectin, laminin, and type IV collagen in a chickenwire distribution, characteristic for these epithelial cells (Campochiaro, Jerdan and Glaser, 1986). The RPE cells also avidly and uniformly incorporated both fluorescently-labeled native and acetylated low density lipoproteins (Elner. Davis and Elner, 1984; Elner, 1986) in contrast to fibroblasts which do not bind or internalize acetylated low density lipoproteins. The RPE cells also failed to stain for factor VIII antigen or with Ulex europaeus I lectin (Vector Laboratories, Burlingame, CA), markers for vascular endothelial cells. Furthermore, sister cultures of the RPE cells used in our IL-6 studies produced IL-8 (neutrophil chemotactic factor) when exposed to rIL- $1 \beta$ and rTNF- $\alpha$, but failed to do so in response to LPS (Elner et al., 1990) that induced $\mathrm{IL}-8$ under the same experimental conditions in vascular endothelial cells (Strieter et al., 1989) and mononuclear phagocytes (Strieter et al., 1990). Taken together, these studies indicate that our RPE cell cultures were pure and uniform and that the results obtained could not be due to contaminating cell types such as macrophages, vascular endothelium, or fibroblasts.

\section{RPE Cell Stimulation with rIL-1 $\beta, r T N F-\alpha$, and LPS}

In all experiments, simultaneous, parallel assays were performed on fourth-passaged RPE cells in 25$\mathrm{cm}^{2}$ sister flasks containing near confluent cells seeded at the same time and density from the same parent cultures. Assayed RPE cells were either unstimulated or treated with human recombinant (r)IL-1 $\beta$ (Upjohn Co., Kalamazoo, MI), human rTNF- $\alpha$ (Cetus Corp., Emeryville, CA), or lipopolysaccharide (LPS; Escher- ichia coli $0111: \mathrm{B} 4$; Sigma). The specific activities of rlL- $1 \beta$ and r'INF- $\alpha$ were 30 and $20 \mathrm{U} \mathrm{ng}^{-1}$, respectively.

Prior to stimulation with human cytokines or LPS, RPE cell cultures were rinsed and placed in fresh, serum-free medium. Assays were begun by overlaying RPE cultures with either $2 \mathrm{ml}$ of serum-free medium (unstimulated control) or $2 \mathrm{ml}$ of medium containing the appropriate amount of rIL- $1 \beta, \mathrm{rTNF}-\alpha$, or LPS. To determine time-dependent induction of RPE IL-6, RPE cultures were exposed to IL-1 $\beta\left(20 \mathrm{ng} \mathrm{ml}^{-1}\right)$, TNF- $\alpha$ (20 $\left.\mathrm{ng} \mathrm{ml}^{-1}\right)$, or LPS $\left(10 \mu \mathrm{g} \mathrm{ml}^{-1}\right.$ ) for $1,2,4,8$ and $24 \mathrm{hr}$. To determine dose-dependent induction of RPE IL-6, RPE cultures were exposed to various concentrations of $\mathrm{IL}-1 \beta$ and TNF- $\alpha\left(20 \mathrm{pg} \mathrm{m}^{-1}\right.$ to $20 \mathrm{ng} \mathrm{ml}^{-1}$ ) and LPS (10 $\mathrm{pg} \mathrm{ml}^{-1}$ to $10 \mu \mathrm{g} \mathrm{ml}^{-1}$ ) in $6-\mathrm{hr}$ assays. Following experimental incubations, conditioned media (CM) were collected, centrifuged to remove particulates, and stored at $-70^{\circ} \mathrm{C}$ until bioassays for IL-6 protein were performed.

\section{RPE Cell IL-6 mRNA Analysis}

Total RPE cell RNA was extracted as previously described (Elner et al., 1990). In brief, the adherent RPE cells were solubilized in $25 \mathrm{~mm}$ Tris, pH 8.0 , containing $4.2 \mathrm{M}$ guanidine isothiocyanate, $9.5 \%$ Sarkosyl, and $0.1 \mathrm{M} \beta$-mercaptoethanol. An equal volume of $100 \mathrm{~mm}$ Tris, $\mathrm{pH} 8 \cdot 0$, containing $1 \cdot 0 \%$ SDS and $10 \mathrm{mM}$ EDTA was then added and the RNA extracted with chloroform-phenol. The alcohol-precipitated RNA was separated by formaldehyde/1\% agarose gels and transblotted to nitrocellulose. The baked blots were prehybridized and then hybridized with a ${ }^{32} \mathrm{P}$-5-end-labeled 30-mer oligonucleotide probe complementary to nucleotides of the published CDNA sequence for human IL-6 (May, Helfgott and Sehgal, 1986). The sequence of the probe was 5'-GGTGAG-TGG-CTG-TCT-GTG-TGG-GGC-GGC-TAC-3'. The probe was $5^{\prime}$-end labeled with $\left[{ }^{32} \mathrm{P}\right]$ adenosine $5^{\prime}$ triphosphate (ICN Biomedicals, Inc, Costa Mesa, CA). Extracted RN $\Lambda$ was separated by electrophoresis, transferred to nitrocellulose, hybridized with the ${ }^{32} \mathrm{P}$ labeled probes, and washed in $6 \times$ standard saline citrate (SSC) and $0.5 \%$ sodium pyrophosphate at $57^{\circ} \mathrm{C}$ for $1 \mathrm{hr}$. The blots were autoradiographed and quantitated by laser densitometry. Equivalent amounts of total RNA loaded per gel lane were assessed by monitoring $28 \mathrm{~s}$ and $18 \mathrm{~s}$ rRNA.

\section{IL-6 Bioassay}

IL-6 levels in RPE cell CM were measured using an extremely specific and sensitive plasmacytoma proliferation assay (Aarden, Lansdorp and de Groot, 1985 ; Van Snick, 1990) involving the IL-6 dependent murine hybridoma cell line B13.29, clone B9 (kindly provided by J. Gauldie, McMaster University, Hamil- 


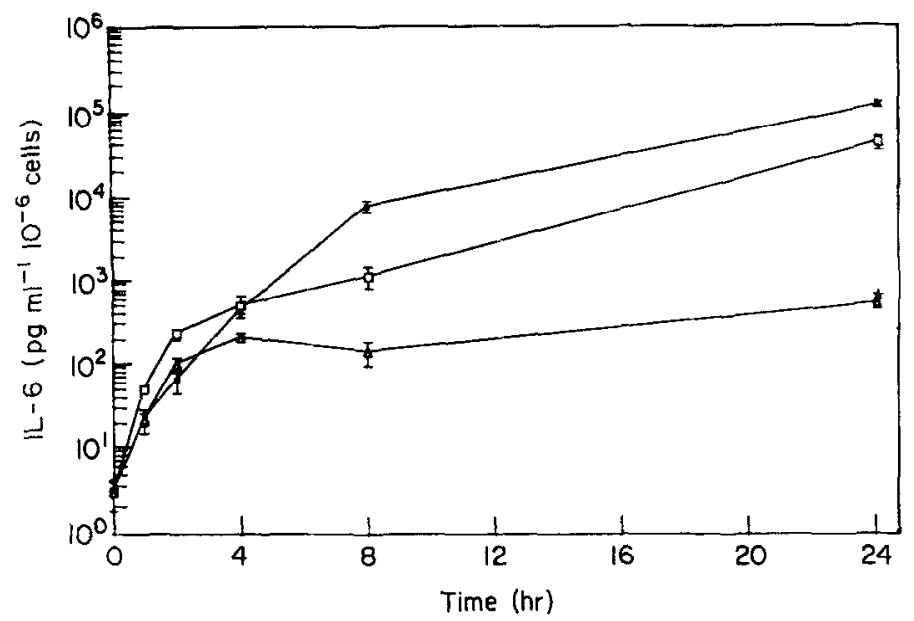

FIG. 1. Time-dependent IL-6 bioactivity in RPE cell conditioned media (CM) after IL-1 $\beta(\square)$, TNF- $\alpha(\square)$, and LPS $(\triangle)$ RPE cell stimulation. Human RPE cells were exposed to $\mathrm{IL}-1 \beta\left(20 \mathrm{ng} \mathrm{ml}^{-1}\right)$, TNF- $\alpha\left(20 \mathrm{ng} \mathrm{ml}^{-1}\right)$ or LPS $\left(10 \mu \mathrm{g} \mathrm{ml}^{-1}\right)$ at $37^{\circ} \mathrm{C}$ for the times indicated. The $C M$ were removed and their $\mathbb{L}-6$ bioactivities measured using a standardized, colorimetric plasmacytoma proliferation assay as described in Materials and Methods. Each value represents the mean of assays performed on separate flasks of RPE cells \pm S.D. CM from RPE cells stimulated for $24 \mathrm{hr}$ with LPS did not contain significantly more activity than media conditioned by unstimulated RPE cells for $24 \mathrm{hr}\left({ }^{*}\right)$.

ton. Ontario) as previously described (Aarden et al., 1987). Briefly, serial dilutions of test samples were incubated with $100 \mu \mathrm{l}$ of $\mathrm{LL}-6$ dependent plasmacytoma cells at a concentration of $5 \times 10^{4} \mathrm{cells} \mathrm{ml}^{-1}$ for $72 \mathrm{hr}$ in a humidified incubator at $37^{\circ} \mathrm{C}$ and $5 \% \mathrm{CO}_{2}$. Proliferation was measured in a colorimetric assay using 3-(4,5-dimethylthiiazol-2-yl)-2,5 diphenyltetrazolium bromide (MTT; Sigma). During the final $6 \mathrm{hr}$ of the plasmacytoma assay, $20 \mu \mathrm{l}$ of MTT $\left(5 \mathrm{mg} \mathrm{ml}^{-1}\right.$ in PBS) was added to each sample. The CM were then aspirated and $100 \mu \mathrm{l}$ of isopropanol acidified with $0.04 \mathrm{M} \mathrm{HCl}\left(3.4 \mu \mathrm{l} \mathrm{ml}^{-1}\right.$ isopropanol) was added. Absorbance at $550 \mathrm{~nm}$ was then measured. Serial dilutions human rIL-6 (R\&D Systems Inc.. Minneapolis, $\mathrm{MN}$ ) were used to generate a standard curve for each assay. IL- 6 concentrations in experimental samples were calculated using the standard curves.

Prior to assays on some CM from RPE cells stimulated with human $\mathrm{rIL}-1 \beta$, aliquots of the samples were pre-incubated with non-immune goat serum or with goat-anti-human rIL-6 IgG antibody (R\&D Systems; $2 \mu \mathrm{g} \mathrm{ml}^{-1}$ ). We found the neutralizing antirIL-6 antibody to stoichiometrically-inhibit human rL-6 (R\&D Systems) activity in our plasmacytoma bioactivity assay and to stoichiometrically-bind rIL-6, but fail to bind $\mathrm{rIL}-1 \beta$, rTNF- $\alpha$, or LPS, in ELISA assays performed according to the method of Ceska et al. (1989).

\section{Statistical Analysis}

Three complete and separate experiments, each performed on a different RPE cell line, were carried out using three flasks of RPE cells for each assay condition. All LL-6 bioassays and ELISA assays on RPE cell CM were performed in triplicate. Data from all experiments were pooled and are expressed as mean pg $\Pi-6 \pm$ S.D. The various groups were compared using Student's $t$ - test and $P<0.01$ were considered to be statistically significant.

\section{Results}

Time-dependence of RPE IL-6 Production Induced by IL- $\beta$ or TNF- $\alpha$

Significant levels of K-6 bioactivity were detected in conditioned media $(C M)$ overlying human RPE cells within $4 \mathrm{hr}$ of $\mathrm{IL}-1 \beta$ (20 $\mathrm{ng} \mathrm{ml}^{-1}$ ) or TNF- $\alpha$ (20 $\mathrm{ng}$ $\mathrm{ml}^{-1}$ ) stimulation. Following initial rapid rises in IL-6 bioactivity activity over $8 \mathrm{hr}$, more gradual increases were observed in CM from cytokine-stimulated RPE cells over the next $16 \mathrm{hr}$ (Fig. 1). The high levels of RPE IL- 6 induced by $\mathbb{L}-1 \beta$ at 8 and $24 \mathrm{hr}$ were significantly greater than those resulting from TNF- $\alpha$ stimulation. At each time point, IL-1 $\beta$ or TNF- $\alpha$ exposure resulted in significantly greater levels of $\mathrm{L}-6$ bioactivity than LPS. Moreover, LPS failed to induce RPE IL-6 production. Accordingly, 24-hr CM from RPE cells stimulated with LPS did not contain significantly more $\Pi-6$ activity $\left(229 \pm 48 \mathrm{pg} \mathrm{ml}^{-1}\right)$ than the low levels found in 24-hr $\mathrm{CM}$ from unstimulated RPE cells $\left(233 \pm 101 \mathrm{pg} \mathrm{m}^{-1}\right)$. LPS also did not induce significant RPE IL-6 in 6-hr doseresponse assays (vide infra). Peak II-6 biological activities in the RPE cell CM were found at $24 \mathrm{hr}$, presumably from accumulating IL- 6 protein corresponding to continued IL-6 mRNA induction.

To insure that the IL-6 bioactivity measured was actual IL-6 protein, IL-6 bioactivity in CM from RPE cell cultures exposed to $\mathrm{L}-1 \beta$ was neutralized with specific goat-anti-human rIL-6 antibody (R\&D Systems). Preincubation with the anti-IL- 6 antibody ( $2 \mu \mathrm{g}$ $\mathrm{ml}^{-1}$ ) significantly reduced measurable IL-6 bioactivity in the CM of RPE cells IL- $1 \beta$ (Table I). Under the same conditions, non-immune goat serum did not reduce measurable IL-6 activity in CM from RPE cultures 
TABLE I

Neutralization of IL-6 bioactivity in human RPE cell conditioned media (CM)

\begin{tabular}{|c|c|c|c|}
\hline \multirow[b]{2}{*}{ RPE stimulation } & \multicolumn{3}{|c|}{ IL-6 $\left(10^{3} \mathrm{pg} \mathrm{ml}^{-1}\right.$ per $10^{6}$ cells $) \pm$ S.D. } \\
\hline & $\mathrm{CM}$ & $\begin{array}{l}\mathrm{CM}+\text { normal } \\
\text { goat serum }\end{array}$ & $\begin{array}{c}\mathrm{CM}+\text { goat-anti-IL-6 } \\
\left(2 \mu \mathrm{g} \mathrm{ml}^{-1}\right)\end{array}$ \\
\hline $\begin{array}{l}\mathrm{IL}-1 \beta\left(20 \mathrm{ng} \mathrm{ml}^{-1}\right) \\
(24 \mathrm{hr})\end{array}$ & $75 \cdot 65 \pm 7.09$ & $83 \cdot 14 \pm 6 \cdot 71$ & $0.99 \pm 0.53$ \\
\hline $\begin{array}{l}\text { IL-1 } \beta\left(2 \mathrm{ng} \mathrm{ml}^{-1}\right) \\
(8 \mathrm{hr})\end{array}$ & $12 \cdot 93 \pm 5 \cdot 57$ & $10 \cdot 57 \pm 6 \cdot 79$ & $0.53 \pm 0.12$ \\
\hline
\end{tabular}
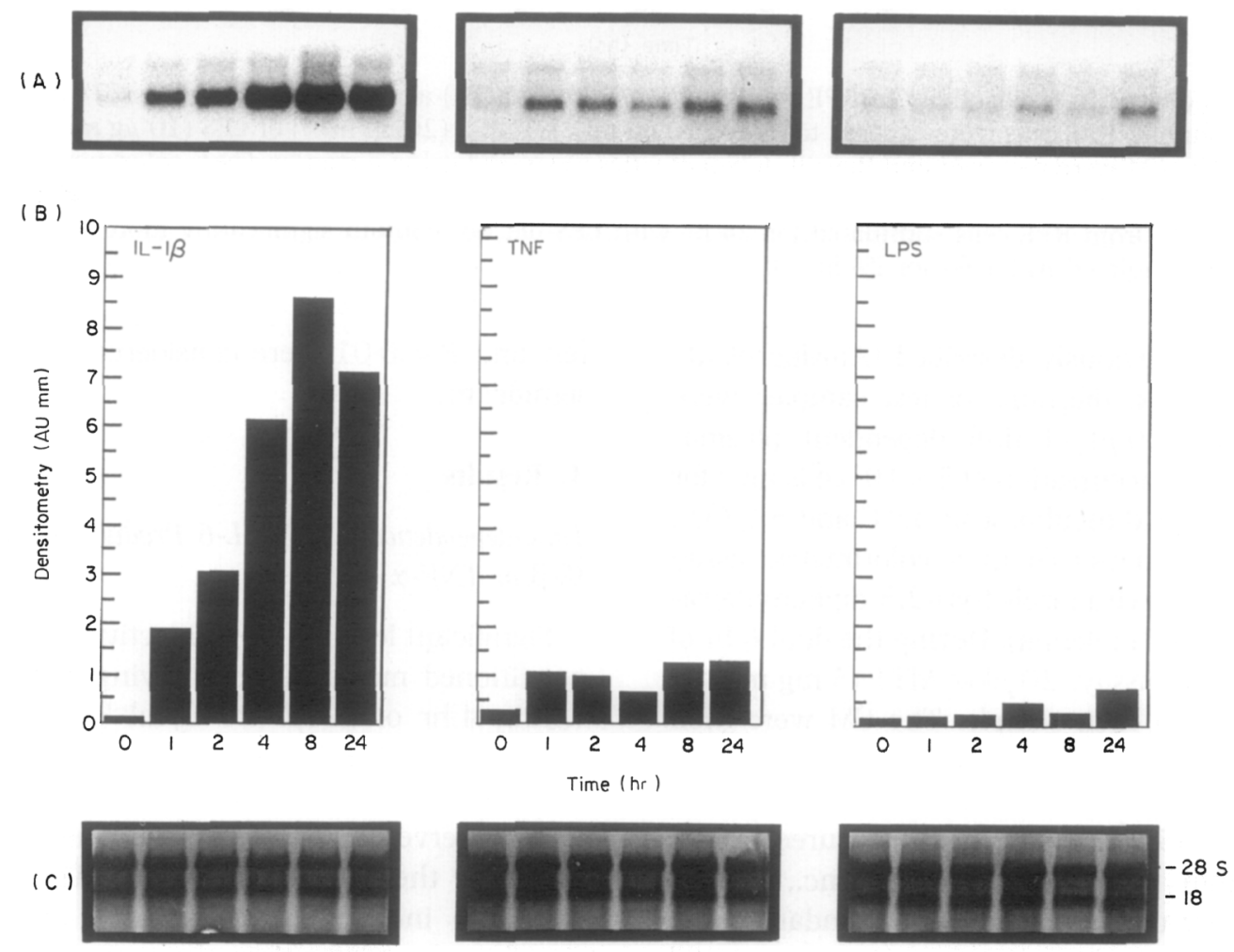

FIG. 2. Time-dependent induction of RPE IL-6 mRNA expression by $\mathrm{L}-1 \beta$, TNF- $\alpha$, and LPS. Human RPE cells were exposed to IL-1 $\beta\left(20 \mathrm{ng} \mathrm{ml}^{-1}\right)$, TNF- $\alpha\left(20 \mathrm{ng} \mathrm{ml}^{-1}\right)$, or LPS $\left(10 \mu \mathrm{g} \mathrm{ml}^{-1}\right)$ at $37^{\circ} \mathrm{C}$ for the times indicated. The media were removed and total cellular RNA was extracted and evaluated by Northern blot analysis for IL- 6 mRNA. A, Twelve-hour autoradiograph of Northern blot analysis of IL- 6 mRNA from RPE cells treated with either IL- $1 \beta$. TNF- $\alpha$, or LPS, respectivcly ; B, relative density of IL-6 mRNA signals determined by laser densitometry; C, 18 and $28 \mathrm{~s}$ rRNA of the same blots. IL- 6 mRNA was not detected in unstimulated RPE cultures assayed for $24 \mathrm{hr}$.

exposed to the same concentrations of $\mathbb{L}-1 \beta$. No detectable IL-6 bioactivity was present in unconditioned media containing IL- $1 \beta$, TNF- $\alpha$, or LPS.

Time-dependence of RPE IL-6 mRNA Expression Induced by IL-1 $\beta$ or TNF- $\alpha$

Northern blots showed increases in steady state RPE IL-6 mRNA expression $1 \mathrm{hr}$ after RPE cell exposure to IL-1 $\beta\left(20 \mathrm{ng} \mathrm{ml}^{-1}\right)$ or TNF- $\alpha\left(20 \mathrm{ng} \mathrm{ml}^{-1}\right)$ (Fig. 2). Time-dependent increases in RPE IL-6 mRNA were observed in RPE cells exposed to $\mathrm{L}-1 \beta$ or TNF- $\alpha$ with peak steady state $\mathrm{L}-6$ mRNA expression occurring at $8 \mathrm{hr}$ for both cytokines. At each time point, IL-1 $\beta$ was substantially more potent in inducing IL-6 mRNA than TNF- $\alpha$. In contrast, LPS $\left(10 \mu \mathrm{g} \mathrm{ml}^{-1}\right)$ did not induce RPE IL-6 mRNA after $24 \mathrm{hr}$ indicating that the higher levels obtained with IL- $1 \beta$ and TNF- $\alpha$ were specific. IL-6 mRNA was not detected in unstimulated RPE cells. RPE cell $\Pi-6$ mRNA migration on the Northern blots was identical to that reported for I-6 derived from other sources (Kishimoto, 1989; Cicco et al., 1990; Elias and Lentz, 1990; Kasahara et al., 1990).

Dose-dependence of RPE IL-6 Production Induced by IL$1 \beta$ or TNF- $\alpha$

Both TNF- $\alpha$ and $\Pi-1 \beta$ elicited progressive and statistically-significant increases in $\mathrm{IL}-6$ bioactivity over a dose range of $20 \mathrm{pg} \mathrm{ml}^{-1}$ to $20 \mathrm{ng} \mathrm{ml}^{-1}$ in 6-hr bioassays (Fig. 3). Within this wide physiologic range 


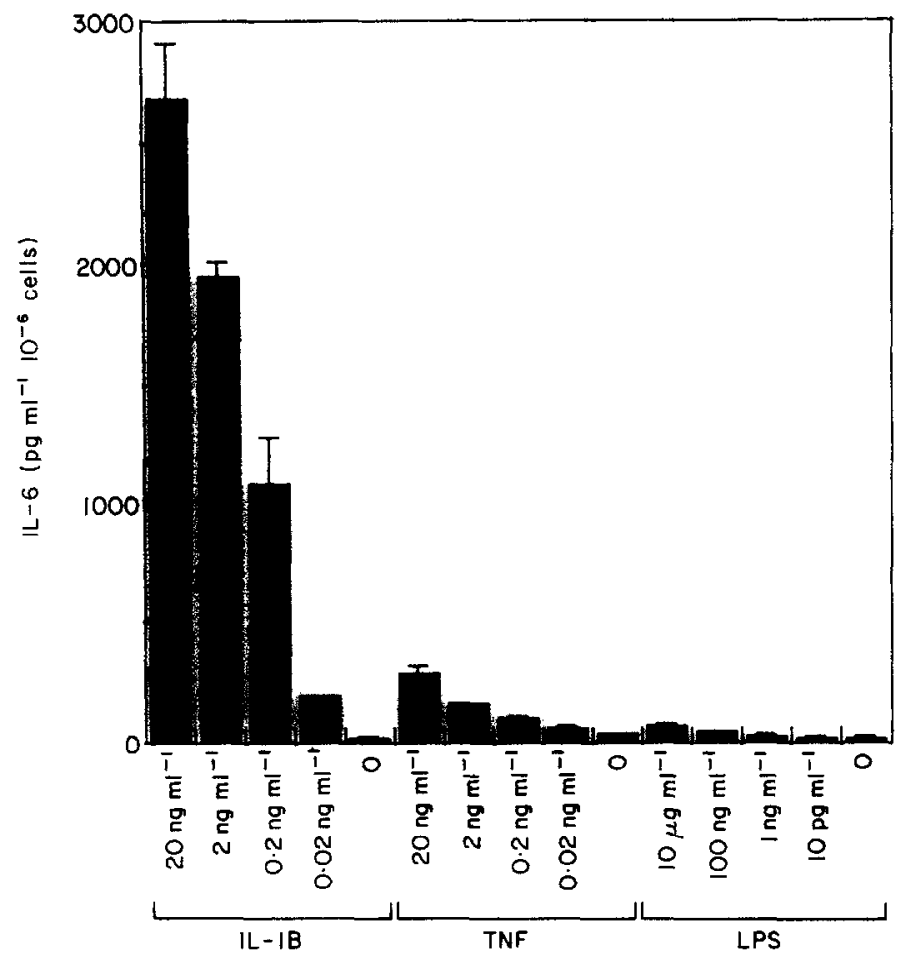

FIG. 3. Dose-dependent IL-6 bioactivity in RPE cell conditioned media (CM) after IL-1 $\beta$. TNF- $\alpha$, or LPS stimulation. Human RPE cells were exposed to IL- $1 \beta$, TNF- $\alpha$, or LPS at the concentrations indicated for $6 \mathrm{hr}$ at $37^{\circ} \mathrm{C}$. The CM were removed and their IL- 6 bioactivities measured using a standardized, colorimetric plasmacytoma proliferation assay as described in Materials and Methods. Each value represents the mean of assays performed on separate flasks of RPE cells \pm s.v. Supernatants from RPE cells stimulated with LPS $\left(10 \mu \mathrm{g} \mathrm{ml}^{-1}\right)$ did not contain significantly more activity than media conditioned by unstimulated RPE cells.

for $\Pi-1 \beta$ and TNF- $\alpha$, maximal $\Pi-6$ bioactivity was found in $\mathrm{CM}$ of RPE cells exposed to cytokine concentrations of $20 \mathrm{ng} \mathrm{ml}^{-1}$ with $50 \%$ of the maximal activity occurred occurring between $0 \cdot 2$ and $2 \cdot 0 \mathrm{ng} \mathrm{ml}^{-1}$. For any given dose, $\Pi-1 \beta$ was significantly more potent and induced approximately ten times more RPE $\Pi-6$ production than TNF- $\alpha$. LPS failed to stimulate significant levels of RPE IL-6 $\left(47 \pm 3 \mathrm{pg} \mathrm{ml}^{-1}\right)$ which were virtually absent in media from unstimulated RPE cultures $\left(39 \pm 6 \mathrm{pg} \mathrm{ml}^{-1}\right)$. Media alone or media containing TNF- $\alpha, \mathrm{IL}-1 \beta$, or LPS did not contain measurable $\mathrm{IL}-6$ in our bioassays.

\section{Dose-dependence of RPE IL-6 mRNA Expression Induced by IL-1 $\beta$ or TNF- $\alpha$}

Steady state IL- 6 gene expression following TNF- $\alpha$ (data not shown) and IL-1 $\beta$ stimulation for $6 \mathrm{hr}$ was also concentration-dependent (Fig. 4), ПL-6 mRNA expression was maximal at an $\mathrm{I}-1 \beta$ concentration of $20 \mathrm{ng} \mathrm{ml} \mathrm{ml}^{-1}$ and was detectable at $20 \mathrm{pg} \mathrm{ml}^{-1}$. Fifty percent of the maximal response occurred between $0 \cdot 2$ and $2 \mathrm{ng} \mathrm{ml}^{-1}$ of $\Pi-1 \beta$. IL-6 mRNA was not detected in unstimulated RPE cells.

\section{Discussion}

Human IL-6 is a $21-28 \mathrm{kDa}$ multifunctional cytokine that induces numerous physiologic and immune responses (Kishimoto, 1989; Le and Vilcek, 1989;
Van Snick, 1990). Although not constitutively produced by normal cells, several cell types including neutrophils, lymphocytes, monocytes, and tissuebased cells such as vascular endothelial cells, fibroblasts and astrocytes elaborate IL-6 upon exposure to LPS or cytokines including $\mathrm{L}-1 \beta$ and TNF- $\alpha$ (Jirik et al., 1989; Kishimoto, 1989; Le and Vilcek, 1989; Sironi et al., 1989; Cicco et al., 1990; Kasahara et al., 1990; Van Snick, 1990). The principal roles of $\Pi-6$ include the induction of terminal B-lymphocyte differentiation (Kishimoto and Hirano, 1988), stimulation of immunoglobulin production by plasma cells (Kishimoto, 1987; Kishimoto and Hirano, 1988), and promotion of T-lymphocyte proliferation, activation, and cytolytic responses (Lotz et al., 1988; Van Snick, 1990). Whereas B-lymphocyte responses to IL-6 are synergized by, but not dependent on $\mathrm{IL}-1 \beta$ (Vink et al., 1986), П-6 effects on T-lymphocytes are principally due to enhanced responsiveness to IL-2, which itself is induced by $\mathrm{IL}-1 \beta$, mainly during the initial stages of Tlymphocyte proliferation and activation (Le and Vilcek. 1989; Van Snick, 1990).

Our results show that RPE cells produce $\Pi-6$ in a time- and dose-dependent manner when stimulated by human $\mathrm{rIL}-1 \beta$ and rTNF- $\alpha$ (Figs 1 and 3 ) and corroborate those recently presented by Planck et al. (1990) who independently found RPE IL-6 production in response to IL- $1 \beta$. Our results also demonstrate that cultured human RPE cells produce steady-state II-6 mRNA (Figs 2 and 4) and levels of biologically active 

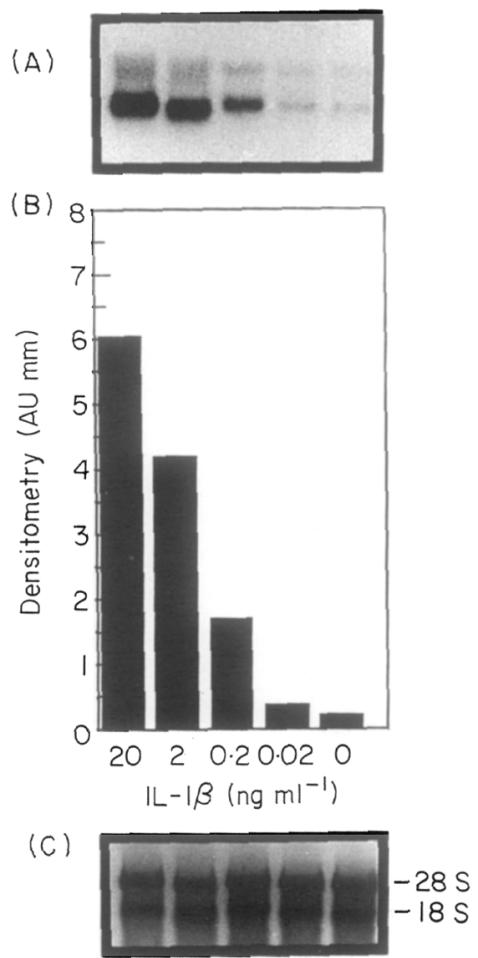

FIg. 4. Progressive RPE II- -6 mRNA expression induced by increasing physiologic concentrations of $\Pi-1 \beta$. Human RPE cells were exposed to the $\mathrm{IL}-1 \beta$ concentrations indicated for $6 \mathrm{hr}$ at $37^{\circ} \mathrm{C}$. The media were removed and total cellular RNA was extracted and evaluated by Northern blot analysis for IL- 6 mRNA. A, Northern blot analysis of mRNA from cells stimulated with increasing doses of IL- $1 \beta$ and probed for IL- 6 mRNA ; B, relative density of the signals determined by laser densitometry; $\mathrm{C}, 18$ and $28 \mathrm{~s}$ rRNA of the same blots.

IL-6 similar to those elaborated by vascular endothelial cells, fibroblasts, and monocytes when exposed to physiologic concentrations of $\Pi_{-1}-1 \beta$ (Kishimoto, 1989 ; Le and Vilcek, 1989; Van Snick, 1990). IL-6 mRNA induction and protein secretion are induced over wide physiologic ranges of $\mathrm{rH}-1 \beta$ and rTNF- $\alpha$ concentrations and are not due to LPS contamination. Half-maximal effects of IL-6 on normal B-lymphocytes are observed at approximately $2 \mathrm{ng} \mathrm{ml}^{-1}$ (Van Snick, 1990), a concentration which we regularly observed in RPE cell CM following IL-1 $\beta$ and TNF- $\alpha$ stimulation.

The RPE and the retinal vascular endothelium form the blood-retina barrier (Marmor and Zinn, 1979). Due to their strategic position in the eye, both cell types are involved in numerous pathologic processes and influence the interactions between circulating leukocytes and the retina (Green, 1985). The RPE and vascular endothelium share several features which may be important in their physiologic and pathologic roles. For example, cytokine-stimulated endothelial cells express surface histocompatibility antigens (Collins et al., 1986) and neutrophil adherence proteins (Gamble et al., 1985) and produce biologically-active arachidonic acid metabolites (Kawakami et al., 1986), tissue factor (Bevilacqua et al., 1986), and platelet- derived growth factor (Hajjar et al., 1987). RPE cells also express histocompatibility antigens (Detrick et al., 1985, 1986; Chan et al.. 1986) and leukocyte adherence proteins (Pavilack et al., 1990), contain high levels of arachidonic acid (Anderson et al., 1976), induce vascular endothelial procoagulant activity (Glaser, 1989), and produce growth factors, including platelet-derived growth factor-like proteins (Campochiaro et al., 1989). Recently, we reported that RPE cells, like vascular endothelial cells, respond to IL- $1 \beta$ and TNF- $\alpha$ by producing neutrophil chemotactic factor (Elner et al., 1990), now designated interleukin-8 (IL-8), that is also chemotactic for lymphocytes at low concentrations (Larsen et al., 1989). This study extends the known similarities between RPE cells and vascular endothelial cells by showing that RPE cells produce biologically active IL- 6 in response to physiologic doses of IL-1 $\beta$ and TNF- $\alpha$. Although we have not studied RPE cytokine production in intact retinal tissue, our findings on cultured RPE cells lead to the contention that cytokinestimulated RPE cells might elicit diapedesis of lymphocytes into injured or inflamed vitreous, retinal, and choroidal tissue by secreting IL-8 (Elner et al., 1990). Concurrent RPE IL-6 secretion may then induce lymphocytic proliferation, B-lymphocyte maturation, and immunoglobulin production as well as T-lymphocyte activation and cytotoxic activity within the eye. The elaboration of IL- 6 by vascular endothelial and RPE cells at the blood-retina barrier emphasizes that these critically-positioned, tissue-based cells may not be passive targets for injury, but may actively participate in ocular inflammatory and immunologic diseases.

Pathologic RPE cell alterations, including HLA-DR antigen expression, are thought to be important in a variety of vascular, inflammatory, degenerative, and dystrophic diseases of the retina and choroid (Marmor and Zinn, 1979; Green, 1985; Detrick et al., 1985 , 1986: Chan et al., 1986). Inflammatory cells, vascular endothelial cells, fibroblasts, astrocytes, and Muller cells which also actively participate in these diseases are known producers of $\mathrm{IL}-1 \beta$ and TNF- $\alpha$ (Roberge et al., 1988; Akira et al., 1990; Hofman and Hinton, 1990) and might thereby induce local RPE IL-6 production in vivo in a manner similar to that observed in vitro. RPE-derived IL-6 may be of particular importance in uveal and retinal inflammatory diseases in which lymphocytes are key participants, including sympathetic ophthalmia, Vogt-Koyanagi-Harada syndrome, and experimental autoimmune uveitis, all of which are thought to involve cell mediated immunity to endogenous antigens present within the eye (Lightman and Chan, 1990). Thus, local production of IL- 6 by RPE cells may enhance lymphocyte proliferation and immune responses in experimental uveitis induced by IL- $1 \beta$, TNF- $\alpha$, or LPS (Rosenbaum et al., 1987, 1988) and experimental lens-induced uveitis in which high choroidal levels of $\mathrm{L}-1$ and TNF 
are found (Attalla, Linker-Israeli and Rao, 1989). The effects of RPE IL-6 on infiltrating lymphocytes in uveitis may be further augmented by ambient intraocular IL- $1 \beta$ and TNF- $\alpha$ levels responsible for inducing RPE $\Pi$ - 6 production and intraocular $\Pi-2$ in uveitis (Hooks, Chan and Detrick, 1988). In fact, high levels of locally-produced IL- 6 have been found in experimental endotoxin-induced uveitis (Hoekzema et al., 1991) as well as in the aqueous humor of patients with Fuchs' heterochromic iridocyclitis and toxoplasma uveitis (Murray et al., 1990) suggesting that IL-6 may be important in the pathogenesis of clinical ocular inflammatory disease.

Apart from its effects on immune responses, IL-6 provides trophic stimuli for neural cells by inducing and maintaining nerve growth factor secretion by astrocytes (Frei et al., 1989) and the differentiation of pheochromocytoma cells lines (Satoh et al., 1988) and cerebral cortical neurons (Hama et al., 1989). It is possible that similar IL-6 stimuli may be important in sensory retina development, maintenance, and repair. The capacity of IL-6 to elicit macrophage-like morphology, increased phagocytic activity, and increased expression of $\mathrm{Fc}$ and $\mathrm{C} 3$ receptors on myeloid cells (Miyaura et al., 1988) may likewise be important as an autocrine stimulus to RPE expression of these features during inflammation and repair.

Identification of RPE-derived cytokines such as IL-6 illuminates important mechanisms through which resident, neural-derived phagocytic RPE cells may participate in ocular physiology and disease.

\section{Acknowledgements}

We thank D. Musch for his expert assistance in statistical analysis. Cetus Corporation for TNF- $\alpha$, the Upjohn Company for IL-1 $\beta$, and the Michigan Eye Bank and Transplantation Center for human eye tissue. This work was supported in part by National Institute of Health Grants HL-31963, HL35276, DK-38149, and EY-07003.

\section{References}

Aarden. L. A., de Groot, E. R., Scaap, O. L. and Lansdorp, P. M. (1987). Production of hybridoma growth factor by human monocytes. Eur. J. Immunol. 17, 1411-6.

Aarden, L. A., Lansdorp, P. M. and de Groot, E. R. (1985). A growth factor for $B$ cell hybridomas produced by human monocytes. Lymphokines 10, 175-85.

Akira, S., Hirano, T., Taga, T. and Kishimoto, T. (1990). Biology of multifunctional cytokines: IL-6 and related molecules (IL-1 and TNF). FASEB J. 4, 2860-7.

Anderson. R. E., Lissandrello, P. M., Maude, M. B. and Matthes. M. T. (1976). Lipids of bovine retinal pigment epithelium. Exp. Eye Res. 23, 149-57.

Attalla, L. R. Linker-Israeli, M. and Rao, N. (1989). Modulation of interleukin 1 and tumor necrosis factor production in experimental lens-induced granulomatous uveitis by arachidonic acid metabolic inhibitors. Invest. Ophthalmol. Vis. Sci. 39 (Suppl.), 469.

Bevilacqua, M. P., Pobers, J. S., Majeau, G. R., Fiers, W., Cotran. R. S. and Gimbrone, M. A. (1986). Recombinant tumor necrosis factor induces procoagulant activity in cultured human vascular endothelium: characterization and comparison with the actions of interleukin 1. Proc. Natl. Acad. Sci. U.S.A. 83, 4533-7.

Campochiaro, P. A., Jerdan, J. A. and Glaser, B. M. (1986). The extracellular matrix of human retinal pigment epithelial cells in vivo and its synthesis in vitro. Invest. Ophthalmol. Vis. Sci. 27, 1615-21.

Campochiaro, P. A., Sugg, R., Grotendorst, G. and Hjelmeland. L. M. (1989). Retinal pigment epithelial cells produce PDGF-like proteins and secrete them into their media. Eye Exp. Res. 49, 217-27.

Ceska, M. F., Effenberger, A. E., Peichl, P. and Pursch, E. (1989). Purification and characterization of monoclonal and polyclonal antibodies to neutrophil activation peptide (NAP-1): the development of highly sensitive ELISA methods for the determination of NAP1 and anti-NAP-1 antibodies. Cytokine 1, 136.

Chan, C. C., Detrick, B., Nussenblatt, R. B., Palestine, A. G. Fujikawa, L. S. and Hooks, J. J. (1986). HLA-DR antigens on retinal pigment epithelial cells from patients with uveitis. Arch. Ophthalmol. 104, 725-9.

Cicco, N. A., Lindemann, A., Content, J., Vandenbussche, P. Lubbert, M., Gauss, J., Mertelsmann, R. and Herrman, F. (1990). Inducible production of interleukin- 6 by human polymorphonuclear neutrophils: role of granulocyte-macrophage colony-stimulating factor and tumor necrosis factor-alpha. Blood 75, 2049-52.

Collins, T., Lapierre, L. A., Fiers, W., Strominger, J. L. and Pober, J. S. (1986). Recombinant human tumor necrosis factor increases mRNA levels and surface expression of HLA-A,B antigens in vascular endothelial cells and dermal fibroblasts in vitro. Proc. Natl. Acad. Sci. UI.S.A. 83, 446-50.

Detrick, B., Newsome, D. A., Percopo, C. M. and Hooks, J. J. (1985). Class II antigen expression and gammainterferon modulation of monocytes and retinal pigment epithelial cells from patients with retinitis pigmentosa. Clin. Immunol. Immunopathol. 36, 201-11.

Detrick, B., Rodrigues, M., Chan, C. C., Tso, M. O. and Hooks, J. J. (1986). Expression of HLA-DR antigen on retinal pigment epithelial cells in retinitis pigmentosa. Am. J. Ophthalmol. 101, 584-90.

Edwards, R. B. (1982). Culture of mammalian retinal pigment epithelium and neural retina. Methods Enzymol. 81, 39-43.

Elias, J. A. and Lentz, V. (1990). IL-1 and tumor necrosis factor synergistically stimulate fibroblast IL-6 production and stabilize IL-6 messenger RNA. J. Immunol. 145, 161-6.

Elner, S. G., Davis, H. R. and Elner, V. M. (1984). Acetoacetylated lipoprotein uptake by retinal pigment epithelium (RPE) cells. Invest. Ophthalmol. Vis. Sci. 25 (Suppl.). 248.

Elner, V. M. (1986). Retinal Pigment Epithelial Cells Exhibit Macrophage-like Features and Functions. Ph.D. Thesis, University of Chicago.

Elner, V. M., Schaffner, T., Taylor, K. and Glagov, S. (1981). Immunophagocytic properties of retinal pigment epithelial cells. Science 211, 74-6.

Elner, V. M., Strieter, R. M., Elner, S. G., Baggiolini, M., Lindley, I. and Kunkel, S. L. (1990). Neutrophil chemotactic factor (IL-8) gene expression by cytokine-treated retinal pigment epithelial cells. Am. J. Pathol. 136, 745-50

Frei, K., Malipiero, U. V., Leist, T. P., ZInkernagel, R. M., Schwab, M. E. and Fontana, A. (1989). On the cellular source and function of interleukin 6 produced in the central nervous system in viral diseases. Eur. J. Immunol. 19. 689-94.

Gamble, J. R., Harlan, J. M., Klebanoff, S. J. and Vadas, M. A. (1985). Stimulation of the adherence of neutrophils to 
umbilical vein endothelium by human recombinant tumor necrosis factor. Proc. Natl. Acad. Sci. U.S.A. 82. $8667-71$.

Glaser, B. M. (1989). Extracellular modulating factors and the control of intraocular neovascularization: an overview. In Retina: Surgical Retina. Vol. 3. (Eds Ryan, S. J., Glaser, B. M. and Michels, R. G.). Pp. 511-2. CV Mosby: St Louis, MO.

Green, W. R. (1985). Retina. In Ophthalmic Pathology: An Atlas and Textbook. (Ed. Spencer, W. H.). Pp. 589-1251. W. B. Saunders: Philadelphia, PA.

Hajjar, K. A., Hajjar, D. P., Silverstein, K. L. and Nachman, R. L. (1987). Tumor necrosis factor-mediated release of platelet-derived growth factor from cultured endothelial cells. J. Exp. Med. 166, 235-45.

Hama, T., Miyamoto, M., Tsukui, H., Nishio, C. and Hatanaka, H. (1989). Interleukin-6 as a neurotrophic factor for promoting the survival of cultured basal forebrain cholinergic ncurons from postnatal rats. Neurosci. Lett. 104, 340-4.

Hoekzema, R., Murray, P. I., van Haren, A. C., Helle, M. and Kijlstra, A. (1991). Analysis of interleukin-6 in endotoxin-induced uveitis. Invest. Ophthalmol. Vis. Sci. 32. 88-95.

Hofman, F. M. and Hinton, D. R. (1990). TNF- $\alpha$ and IL- $1 \beta$ is induced in HIV-infected retina. Invest. Ophthalmol. Vis. Sci. 31 (Suppl.), 64.

Hooks, J. J., Chan, C. C. and Detrick, B. (1988). Identification of the lymphokines, interferon-gamma, and interleukin2 in inflammatory eye disease. Invest. Ophthalmol. Vis. Sci. 29, 1444-51.

Jirik, F. R., Podor, T. J., Hirano, T., Kishimoto, T., Loskutoff, D. J., Carson, D. A. and Lotz, M. (1989). Bacterial lipopolysaccharide and inflammatory mediators augment IL- 6 secretion by human endothelial cells. $J$. Immunol. 142, 144-7.

Kasahara, T., Yagisawa, H., Yamashita, K., Yamaguchi, Y. and Akiyama, Y. (1990). IL1 induces proliferation and IL6 mRNA expression in a human astrocytoma cell line: positive and negative modulation by chorela toxin and cAMP. Biochem. Biophys. Res. Commun. 167, 1242-8.

Kawakami, M., Ishibashi, S., Ogawa, H., Murase, T., Takaku, F. and Shibata, S. (1986). Cachectin/TNF as well as interleukin-1 induces prostacyclin synthesis in cultured vascular endothelial cells. Biochem. Biophys. Res. Commun. 141, 482-7.

Kishimoto. T. (1987). B-cell stimulatory factors (BSFs): molecular structure, biological functions, and regulation of expression. J. Clin. Immunol. 7, 343-55.

Kishimoto, T. (1989). The biology of interleukin-6. Blood 74, $1-10$.

Kishimoto, T. and Hirano, T. (1988). Molecular regulation of B lymphocyte response. Ann. Rev. Immunol. 6, $485-512$.

Larsen, C. G., Anderson, A. O., Apella, E., Oppenheim, J. J. and Matushima K. (1989). The neutrophil-activating protein (NAP-1) is also chemotactic for $\mathrm{T}$ lymphocytes. Science 243, 1464-6.

Le, J. and Vilcek, J. (1989). Interleukin 6: a multifunctional cytokine regulating immune reactions and the acute phase protein response. Lab. Invest. 61, 588-602.

Lightman, S., Chan, C. (1990). Immune mechanisms in choroidoretinal inflammation in man. Eye 4, 345-53.

Lotz, M.. Jirik, F., Kabouridis, P., Tsoukas, C., Hirano, T., Kishimoto, T. and Carson, D. (1988). B-cell stimulating factor 2 /interleukin 6 is a costimulant for human thymocytes and T-lymphocytes. J. Exp. Med. 167, 1253-8.

Marmor, M. F. and Zinn, K. M. (1979). The Retinal Pigment Epithelium. Harvard University: Cambridge, MA.

May, L. T., Helfgott, D. C. and Sehgal, P. B. (1986). Antibeta-interferon antibodies inhibit the increased expression of HLA-B7 mRNA in tumor necrosis factortreated human fibroblasts: structural studies of the beta 2 interferon involved. Proc. Natl. Acad. Sci. U.S.A. 83. 8957.

Miyaura, C.. Onozaki, K., Akiyama, Y., 'Taniyama, T., Hirano, T., Kishimoto, T. and Suda, T. (1988). Recombinant human interleukin 6 (B-cell stimulatory factor 2) is a potent inducer of differentiation of mouse myeloid leukemia cells (M1). FEBS Letts 234, 17-21.

Murray, P. I., Hoekzema, R., van Haren, M. A. C., de Hon, F. D. and Kijlstra, A. (1990). Aqueous humor interleukin-6 lcvels in uveitis. Invest. Ophthalmol. Vis. Sci. 31, 917-20.

Pavilack, M. A., Elner, S. G., Feldman, L. E., Todd, R. F. and Elner, V. M. (1990). Human RPE (HRPE) cells express leukocyte integrins and intercellular adhesion molecules. Invest. Ophthalmol. Vis. Sci. 31 (Suppl.), 372.

Planck, S. R., Dang, T. T., Ansel, J. C., Robertson, J. E. and Rosenbaum. J. T. (1990). Retinal pigment epithelial cells secrete interleukin- 6 in response to interleukin-1. Invest. Ophthalmol. Vis. Sci. 31 (Suppl.). 372.

Roberge, F. G., Caspi, R. R. and Nussenblatt, R. B. (1988). Glial retinal Muller cells produce IL-1 activity and have a dual effect on autoimmune $\mathrm{T}$ helper lymphocytes. $J$. Immunol. 140, 2193-6.

Rosenbaum, J. T., Howes, E. L., Rubin, R. M. and Samples, J.R. (1988). Ocular inflammatory effects of intravitreally injected tumor necrosis factor. Am. J. Pathol. 133, 47-53.

Rosenbaum. J. T., Samples, J. R., Hefeneider, S. H. and Howes, E. L. (1987). Ocular inflammatory effects of intravitreal interleukin 1. Arch. Ophthalmol. 105, $1117-20$.

Satoh. T., Nakamura, S., Taga, T., Matsuda, T., Hirano, T., Kishimoto, T. and Kaziro, Y. (1988). Induction of neuronal differentiation in PC12 cells by B-cell stimulatory factor 2/interleukin 6. Mol. Cell. Biol. 8, 3546-9.

Sironi, M., Breviario, F., Proserpio, P., Biondi, A., Vecchi, A., van Damme, J., Dejana, E. and Mantovani, A. (1989). IL-1 stimulates IL-6 production in endothelial cells. J. Immunol. 142, 549-53.

Strieter, R. M., Chensue, S. W., Basha, M. A., Standiford, T. J., Lynch, J. P., Baggiolini, M. and Kunkel, S. L. (1990). Human alveolar macrophage gene expression of interleukin- 8 by tumor necrosis factor-alpha, lipopolysaccharide, and interleukin-1-beta. Am. J. Respir. Cell. Mol. Biol. 2, 321-6.

Strieter, R. M., Kunkel, S. L., Showell, H. J., Remick, D. G., Phan, S. H., Ward, P. A., and Marks, R. M. (1989). Endothelial cell gene expression of a neutrophil chemotactic factor by TNF- $\alpha$, LPS, and IL- $1 \beta$. Science 243 , 1467-9.

Van Snick, J. (1990). Interleukin-6: an overview. Ann. Rev. Immunol. 8, 253-78.

Vink, A., Coulie, P. G., Wauters, P., Nordan, R. P. and Van Snick, J. (1986). B cell growth and differentiation activity of interleukin-HP1 and related murine plasmacytoma growth factors. Synergy with interleukin-1. Eur. J. Immunol. 18, 607-12. 